\title{
NOTCH1 wt Allele
}

National Cancer Institute

\section{Source}

National Cancer Institute. NOTCH1 wt Allele. NCI Thesaurus. Code C51562.

Human NOTCH1 wild-type allele is located in the vicinity of 9q34.3 and is approximately

$51 \mathrm{~kb}$ in length. This allele, which encodes neurogenic locus notch homolog protein 1 protein, plays a role in developmental processes by controlling cell fate decisions. 